Disgraceful Matters 
This page intentionally left blank 


\section{Disgraceful Matters}

The Politics of Chastity in Eighteenth-Century China

\section{Janet M. Theiss}


University of California Press

Berkeley and Los Angeles, California

University of California Press, Ltd.

London, England

(C) 2004 by the Regents of the University of California

Library of Congress Cataloging-in-Publication Data

Theiss, Janet M., I964-

Disgraceful matters : the politics of chastity in eighteenth-century China / Janet M. Theiss.

p. $\mathrm{cm}$.

Includes bibliographical references and index. ISBN 0-520-24033-2 (alk. paper)

I. Chastity. 2. Women-China-Social conditions. 3. China-Social conditionsI644-I9I 2. I. Title: Politics of chastity in eighteenth-century China. II. Title.

BJI533.C4T $49 \quad 2004$

I $76^{\prime} .095 \mathrm{I}-\mathrm{dc} 22$

2004009I 86

Manufactured in the United States of America

$\begin{array}{llllllllll}\text { I3 } & \text { I2 } & \text { II } & \text { IO } & 09 & 08 & 07 & 06 & 05 & 04\end{array}$

$\begin{array}{llllllllll}\text { IO } & 9 & 8 & 7 & 6 & 5 & 4 & 3 & 2 & \text { I }\end{array}$

Printed on Ecobook 50 containing a minimum 50\% post-consumer waste, processed chlorine free. The balance contains virgin pulp, including $25 \%$ Forest Stewardship Council Certified for no old growth tree cutting, processed either TCF or ECF. The sheet is acid-free and meets the minimum requirements of ANSI/NISO Z39.48-I992 (R I997) (Permanence of Paper). 
For

Norman Theiss and Judith Eheim Theiss,

my first and foremost models of virtue and scholarship 
This page intentionally left blank 